\title{
Genericity and the Denotation of Common Nouns in Brazilian Portuguese*
}

\author{
(A Genericidade e a Denotação dos Nomes Comuns em Português)
}

Ana MÜLleR

(University of São Paulo, Brasil)

\begin{abstract}
This paper investigates what the semantics of generic sentences in Brazilian Portuguese (BP) says about the denotation of Noun Phrases in that language. More specifically, it addresses the syntactic and semantic differences among the indefinite nominals that get a generic interpretation in BP. The paper may also be taken to test well-known bypotheses about the functioning of genericity in natural languages.
\end{abstract}

KEY-WORDs: Semantics; Syntax; Genericity; Common nouns.

RESUMO: Este artigo investiga o que o comportamento da semântica das sentenças genéricas no Português Brasileiro (PB) diz sobre a denotação dos Sintagmas Nominais nesta língua. Mais especificamente ele discute as diferenças sintáticas e semânticas entre os nominais indefinidos que possuem uma leitura genérica no PB. Este artigo também pode ser considerado um teste para hipóteses já bem-estabelecidas sobre ofuncionamento da genericidade nas linguas naturais.

PalavRas-CHaVe: Semântica; Sintaxe; Genericidade; Nomes comuns.

\section{Introduction}

The goal of this paper is to investigate what the semantics of generic sentences in Brazilian Portuguese (BP) says about the denotation of Noun Phrases (NPs) in that language. More specifically, I want to address the

\footnotetext{
* This paper was presented at the Seminarios em Teoria Gramatical, Universidade de São Paulo, 15 March 2001 and at the SULA, UMass, 20-22 April 2001. I thank both audiences for their criticisms and comments. I also thank Angelika Kratzer for cristicisms and comments.
}

D.E.L.T.A., 18:2, 2002 (287-308) 
syntactic and semantic differences among the indefinite nominals that get a generic interpretation in BP: the generic indefinite, the bare singular and the bare plural. The paper may be also taken as a test of well-known hypotheses about the functioning of genericity in natural languages.

My main claims in this paper are:

(i) The generic indefinite, the bare singular and the bare plural are heimian indefinites in BP (cf. Heim 1982).

(ii) The basic denotation of the common noun in $\mathrm{BP}$ is mass.

(iii) Bare singulars in BP are not full Determiner Phrases (DPs).

(iv) $\mathrm{BP}$ has both a SING(ular) and a PL(ural) operator that turn the denotation of common nouns from mass to count.

The general outline of the paper is as follows. In section 1, I present the basic facts on the expression of genericity in BP. Section 2 investigates the import of number morphology for nominals in $\mathrm{BP}^{1}$. In section 3, I propose an interpretation for common nouns in BP, and an interpretation for both a singular and a plural operator which I claim to exist in that language. In section 4, I apply the proposed framework to derive the logical forms of sentences with generic indefinites in BP. Section 5 deals with the syntax and semantics of indefinites in BP. Finally, a summary is offered.

\section{Basic Facts about Generic Nominals in Brazilian Portuguese}

In this section, I will try to establish the basic facts about the denotation of generic nominals in BP. In BP, all kinds of nominal expressions may be used to express genericity: singular (1) and plural (2) definite nominals, indefinite nominals (3), the bare singular (4) and the bare plural (5).

(1) O automóvel chegou no Brasil em 1924. The-sg automobile arrived in-the Brasil in 1924. ('The automobile reached Brazil in 1924')

1 Throughout this paper I will use the term 'nominal' or 'nominal expression' when I wish to remain neutral to the debate of whether the nominal constituent is a Determiner Phrase or a Noun Phrase. 
(2) As cobras são animais perigosos. The-pl snakes are animals dangerous ('Snakes are dangerous animals')

(3) Um brasileiro come feijão com arroz. A Brazilian eats bean with rice ('Brazilians eat rice and beans')

(4) Homem não chora. Man not cries ('Men don't cry')

(5) Professores trabalham muito. Teachers work much ('Teachers work a lot')

Natural languages are known to make use of two different devices to express genericity: kind referring expressions - expressions that denote kinds (Carlson 1977a,b), and generic quantification - sentences under the scope of a generic operator (Wilkinson 1991, Gestner and Krifka 1993). A number of diagnostic tests help distinguish the two types of genericity (Krifka et al. 1995, Gestner \& Krifka 1993). ${ }^{2}$ In (i)-(iii) I apply the tests to generic nominals in BP.

(i) There are some predicates with argument places that can be filled only by kind-referring expressions. ${ }^{3}$ Be extinct is one of those predicates. In (6) and (7) we see that the definite singular and the bare plural behave like kind-referring expressions, whereas the generic indefinite and the bare singular do not.

(6) O dodo está extinto.

the dodo is extinct

('The dodo is extinct')

(7) *Um dodo/*Dodo/Dodos está(estão) extinto(s).

a dodo/ dodo/dodos is(are) extinct(-pl)

('Dodos are extinct')

\footnotetext{
2 For simplicity, the definite plural DP in BP will be left out of the discussion below because my main point will be about the indefinite nominals. Also most analysis take the generic definite plural to be just a 'normal' definite plural, that is, the sum of all atomic elements in the denotation of the NP (Link 1983 and Chierchia 1998).

3 In these examples, and in the rest of the paper, the asterisk and the question mark express judgements for the generic non-taxonomic reading of the NPs and not for its other possible readings which may very well be available.
} 
(ii) Generic sentences are stative. Consequently, a sentence with an episodic predicate will only be able to express genericity if one of its arguments is a kind-referring expression. Sentences (8)-(11) show the same pattern as in test (i), that is, the definite singular and the bare plural behave as kind-referring expressions, whereas the generic indefinite and the bare singular do not.

(8) O automóvel chegou no Brasil no século XX. The automobile arrived in-the Brazil in-the century XX ('The automobile arrived in Brazil in the $20^{\text {th }}$ century')

(9) *Um automóvel chegou no Brasil no século XX. An automobile arrived in-the Brazil in-the century XX

(10) *Automóvel chegou no Brazil no século XX. Automobile arrived in-the Brazil in-the century XX

(11) ?Automóveis chegaram no Brasil no século XX. Automobiles arrived in-the Brazil in-the century XX ('Automobiles arrived in Brazil in the $20^{\text {th }}$ century')

(iii) Kind-referring expressions sound 'strange' when made out of not well-established kinds. The pattern one gets from sentences (12)(15) is like this: the definite DP behaves as a kind-referring expression, whereas the generic indefinite, and both the bare singular and the bare plural do not.

(12) a. A garrafa de Coca tem gargalo estreito. The bottle of Coke has neck narrow ('The Coke bottle has a narrow neck')

b. ??A garrafa verde tem gargalo estreito. The bottle green has neck narrow

(13) a. Uma garrafa de Coca tem gargalo estreito.

A bottle of Coke has neck narrow ('A Coke bottle has a narrow neck')

b. Uma garrafa verde tem gargalo estreito.

A bottle green has neck narrow ('A green bottle has a narrow neck') 
(14) a. Garrafa de Coca tem gargalo estreito. Bottle of Coke has neck narrow ('Coke bottles have a narrow neck')

b. Garrafa verde tem gargalo estreito. Bottle green has neck narrow ('Green bottles have narrow necks')

(15) a. Garrafas de Coca têm gargalo estreito. Bottles of Coke have neck narrow ('Coke bottles have narrow necks')

b. Garrafas verdes têm gargalo estreito. Bottles green-pl have neck narrow ('Green bottles have narrow necks')

Table 1 below summarizes the behavior of generic nominals in BP relative to the tests (i)-(iii).

\begin{tabular}{lcccc}
\hline & $\begin{array}{c}\text { Singular Definite } \\
\text { Generic }\end{array}$ & $\begin{array}{c}\text { Generic } \\
\text { Indefinite }\end{array}$ & $\begin{array}{c}\text { Bare } \\
\text { Singular }\end{array}$ & $\begin{array}{c}\text { Bare } \\
\text { Plurar }\end{array}$ \\
\hline Kind-predicates & OK & $\mathrm{X}$ & $\mathrm{X}$ & $\mathrm{OK}$ \\
\hline Episodic sentences & $\mathrm{OK}$ & $\mathrm{X}$ & $\mathrm{X}$ & $\mathrm{OK}$ \\
\hline Not well-stablished kinds & $\mathrm{X}$ & $\mathrm{OK}$ & $\mathrm{OK}$ & $\mathrm{OK}$ \\
\hline
\end{tabular}

Table 1: The behavior of generic nominals.

This descriptive picture leads us to the following claims:

- The singular definite generic is a kind-referring expressions in Brazilian Portuguese.

- The generic indefinite and the bare singular are not able to denote kinds. Their genericity must stem from their participating in generically quantified sentences. They are heimian indefinites, and as such carry a free variable that gets bound by a generic sentential operator (cf. Heim 1982).

- The bare plural in BP is similar to the English bare plural and is probably ambiguous between a kind-referring and an indefinite interpretation. ${ }^{4}$

\footnotetext{
4 See Krifka et al. 1995 among others.
} 
Other data reinforce these generalizations. Sentences (16) and (17), typically kind-referring contexts, are good with both the definite singular and the bare plural, but bad with generic indefinites. ${ }^{5}$

(16) a. O lobo está aumentando de tamanho quanto mais para o norte nós viajamos. The wolf is increasing of size as more to the north we travel ('The wolf is getting bigger as we travel north')

b. *Um lobo está aumentando de tamanho quanto mais para o norte nós viajamos. A wolf is increasing of size as more to the north we travel

c. *Lobo está aumentando de tamanho quanto mais para o norte nós viajamos. Wolf is increasing of size as more to the north we travel

d. Lobos estão aumentando de tamanho quanto mais para o norte nós viajamos. Wolves are increasing of size as more to the north we travel ('Wolves are getting bigger as we travel north')

(17) a. O homem pôs o pé na Lua em 1969. The man put the foot in-the Moon in 1969 ('The man set foot on the Moon in 1969')

b. *Um homem pôs o pé na Lua em 1969. A man put the foot in-the Moon in 1969

c. *Homem pôs o pé na Lua em 1969. Man put the foot in-the Moon in 1969

d. ?Homens puseramo pé na Lua em 1969. Men put the foot in-the Moon in 1969 ('Men set foot on the Moon in 1969')

A caveat should be put forward as far as the behavior of the bare plural in BP is concerned. The bare plural belongs very much to the written language register. The most usual oral nominal forms that express genericity in BP are either the definite singular or the bare singular.

From this point on, I'll leave kind-referring expressions like the definite singular DP aside, and focus on indefinite generic expressions in BP. These will be analyzed as heimian indefinites, so that a sentence like (5), repeated below as (18a), will have a logical form as in (18b) that is paraphrased in (18c). ${ }^{6}$

5 Note that I am calling the indefinite generic, the bare plural and the bare singular generic indefinites in order to express that they are indefinite nominals with a generic interpretation.

6 See Muller 2000 for a more detailed account of genericity in BP. The notation adopted here is from Krifka et al. 1995. 
(18) a. Professores trabalham muito.

('Teachers work a lot')

b. GEN $[\mathrm{x} ;]$ (x are-teachers; $\mathrm{x}$ work-a-lot)

c. Usually, if $\mathrm{x}$ is a teacher, $\mathrm{x}$ works a lot

\section{Number and the Interpretation of Indefinites in BP}

This section claims that number morphology has semantic import on number in BP.

The first evidence comes from the behavior of anaphoric possessives in BP. Seu is an anaphoric third person possessive in BP. It must have a sentential antecedent and is best analyzed as a bound pronominal (cf. Negrão \& Müller 1998). The denotation of seu then co-varies with the denotation of the indefinite subject in (19a)-(c).

Seu gets different interpretations relative to the type of its antecedent. When the antecedent is a generic indefinite, the possessive DP is interpreted as atomic (19a). When the antecedent is a bare singular, the possessive DP is unmarked for number (19b). Finally, when the antecedent is a bare plural, the possessive DP is molecular, that is, its denotation, must have two or more entities (19c).

(19) a. Uma lagartixa sempre perde seu rabo.

A gecko always looses its tail-one tail per gecko ('A gecko always looses its tail')

b. Lagartixa sempre perde seu rabo.

Gecko always looses its tail - an indefinite number of tails per gecko ('Geckos always loose their tails')

c. Lagartixas sempre perdem seus rabos. geckos always loose their tails - two or more tails per gecko ('Geckos always loose their tails')

Interestingly, the bare singular is not only unmarked for number, but behaves as non-discrete. In (20), Jorge reads an indefinite number of magazines after dinner, he may one day read one magazine, the other day he may read three magazines and in another day he may read just some pages of a magazine. And in (21), Jorge eats an indefinite number of apples. The sentence is still true if he eats $1 / 4$ of an of an apple every day. 
(20) Jorge sempre lê revista depois do jantar. Jorge always reads magazine after of-the dinner ('Jorge always reads magazines after dinner')

(21) Jorge normalmente come maçã de sobremesa. Jorge usually eats apple of desert ('Jorge usually has an apple for desert')

The second evidence comes from the fact that all types of indefinite subjects go with all types of indefinite objects and the effect on number is the same as in (19)-(20) above. ${ }^{7}$ The effect on the semantic number may be observed in sentences (22)-(24). The object with the indefinite article is necessarily atomic ('Unicorns have one horn'). The bare singular object is totally unmarked for number ('Unicorns have any number of horns'). And, finally, the bare plural object denotes two or more entities ('Unicorns have two or more horns'). Therefore this is not a syntactic phenomenon related to agreement - BP does not seem to have dependent plurals.

(22) Um unicórnio tem um chifre/chifre/chifres.

A unicorn has a horn/horn/horns

('A unicorn has a horn/an indefinite $\mathrm{n}^{\circ}$ of horns/ two or more horns')

(23) Unicórnio tem um chifre/chifre/chifres.

Unicorn has a horn/horn/horns

('Unicorns have a horn/an indefinite $\mathrm{n}^{\circ}$ of horns/ two or more horns')

(24) Unicórnios têm um chifre/chifre/chifres.

Unicorns have a horn/horn/horns

('Unicorns have a horn/an indefinite $\mathrm{n}^{\circ}$ of horns/ two or more horns')

Another type of evidence for the different semantics of the three indefinite nominals comes from reciprocals. Reciprocals can only be used with the bare plural (25c). The denotation of the bare singular does not seem to provide countable individuals for the reciprocals (25b). On the other hand, the generic indefinite provides one atom at a time, so reciprocity is not possible (25a).

Collective readings are possible but I will not consider them here. 
(25) a. *Um brasileiro detesta um ao outro.

A Brazilian hates one to-the other

b. *Brasileiro detesta um ao outro. Brazilian hates one to-the other

c. Brasileiros detestam uns ao outros. Brazilians hate ones to-the others ('Brazilians hate each other')

Finally, the bare singular is not able to provide a domain for cada ('each') - a distributive quantifier that must have a countable (atomic/ molecular) domain to distribute over (Negrão 2001). This may be seen in sentences (26a)-(c), where the use of a bare singular as a distributee for a quantified subject with cada causes ungrammaticality.

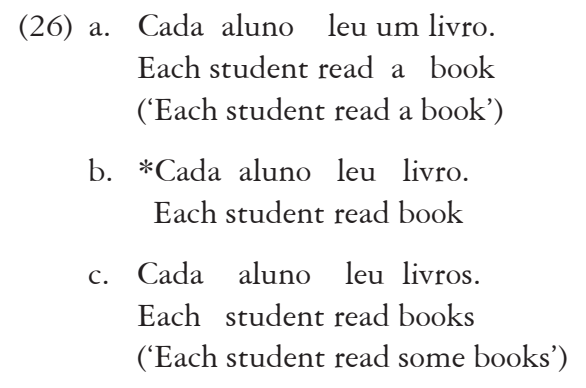

The descriptive generalizations relative to the semantic number of indefinite nominals in BP are:

(i) Bare singulars in BP are not atomized or specified for number.

(ii) The indefinite DP denotes atomic entities.

(iii) The bare plural denotes molecular (countable, but not atomic) entities.

\section{The Interpretation of Common Nouns and of the Plural and the Singular Operator in Brazilian Portuguese}

Based on the behavior of the bare singular in BP with reference to its semantic number and countability, I will claim that the denotation of a 
singular common noun in Brazilian Portuguese is mass (cf. Link 1983 and Higginbotham 1995 for mass nouns).

The use of the bare singular is extremely pervasive in BP. Sentences (28a)-(c) would be perfect answers to question (27). And sentences (30a)(c) are perfect answers to question (29). So the mass-like behavior of the bare singular does not seem to be an effect of an application of the universal grinder. This is accounted for if we take the denotation of the common noun in BP to be mass, in that it contains all portions of matter, all atoms and all molecules of the substance denoted by the noun (cf. Link 1983).

(27) O que que você fez hoje de manhã?

The what that you did today of morning

('What did you do this morning?')

(28) a. Eu li revista.

I read magazine

('I read magazines')

b. Eu comprei sapato.

I bought shoe

('I bought shoes')

c. Eu tirei fotografia.

I took picture

('I took pictures')

(29) O que você gosta de fazer?

The what you like of to-do

('What do you like to do?)

(30) a. Eu gosto de escrever carta.

I like of write letter

('I like to write letters')

b. Eu gosto de cuidar de cachorro.

I like of take-care of dog

('I like to take care of dogs')

c. Eu gosto de ver filme.

I like of see film

('I like to see filmes') 
More evidence for the mass denotation of common nouns in BP comes for their participating in sentences like (31) and (32). ${ }^{8}$

(31) Tem muita mala no carro

Has much suitcase in-the car

('There are many suitcases in the car')

(32) Eu já escrevi carta o suficiente por hoje. I already wrote letter the enough for today ('I wrote enough letters for today')

As we have seen in the previous section, number morphology has semantic meaning in BP. Number morphemes then may be seen as operators on the denotations of Noun Phrases. They are responsible for turning common nouns, which are mass, into count nouns ${ }^{9}$. These operators are defined in (33) and (34). They apply at the DP level.

(33) The singular operator:

$\mathrm{SG}=\lambda \mathrm{P} \lambda \mathrm{x}[\mathrm{P}(\mathrm{x}) \wedge \operatorname{At}(\mathrm{x})]^{10}$

At (a): $a$ is a count individual.

(34) The plural operator:

$\mathrm{PL}=\lambda \mathrm{P} \lambda \mathrm{x}[\mathrm{P}(\mathrm{x}) \wedge \operatorname{Mol}(\mathrm{x})]$

Mol (a): a is a molecular individual (an individual sum of two or more count individuals) (cf.Link 1983).

The result of applying the SG(singular) operator to a common noun is getting the set of atomic entities in the denotation of the common noun or NP as exemplified in (35). For a world with just 3 magazines the denotation of SG (magazine) would be as in (36).

\footnotetext{
8 Evidently much more needs to be said in order to get a clearer picture of the denotation of common nouns in BP. One point that needs further looking is the fact that although classic "count nouns' occur in classic mass contexts, the reverse is not true for classic mass nouns. I leave this for future research.

9 See Cheng and Sybesma 1999 for a similar proposal for classifiers in Chinese.

$10[[A t a]\}:=1$ iff $[[a]] \in A$, where $A$ is the set of atomic entities of the domain of discourse. $[[$ Mol a $]\}:=1$ iff $[[a]] \in{ }^{+} A$ where is the set of plural entities (see Link 1983 for a definition of the ${ }^{+}$operator).
} 
(35) $\mathrm{SG}($ magazine $)=\lambda \mathrm{P} \lambda \mathrm{x}[\mathrm{P}(\mathrm{x}) \wedge \operatorname{At}(\mathrm{x})]($ magazine $)$ $=\lambda \mathrm{x}[$ magazine $(\mathrm{x}) \wedge \operatorname{At}(\mathrm{x})]$

(36) $[[\mathrm{SG}$ (magazine) $]]=\left|\begin{array}{lll}\mid \mathrm{a} & \mathrm{b} & \mathrm{c}\end{array}\right|$

The application of the PL (plural) operator to a common noun gives us a lattice formed by all non-atomic entities (37). Again, for a world with just 3 cookies, (38) would be the denotation of 'PL (cookie)'.

(37) $\mathrm{PL}($ magazine $)=\lambda \mathrm{P} \lambda \mathrm{x}[\mathrm{P}(\mathrm{x}) \wedge \operatorname{Mol}(\mathrm{x})]($ magazine $)$

$=\lambda \mathrm{x}[$ magazine $(\mathrm{x}) \wedge \operatorname{Mol}(\mathrm{x})]$

(38) $[[$ PL (magazine) $]]=\left|\begin{array}{ccc}a \oplus b \oplus c & \\ & \mathrm{a} \oplus \mathrm{c} & \\ \mathrm{a} \oplus \mathrm{b} & & \mathrm{b} \oplus \mathrm{c}\end{array}\right|$

There are two number paradigms for the Determiner Phrase in BP. In standard BP all lexical categories in the DP are marked for number (39), whereas in the non-standard variant only the determiner gets the plural morphology (40). The Determiner Phrase then seems to be the locus of number in BP.

(39) Standard:

a bolacha gostosa / as bolachas gostosas the-SG cookie tasty / the-PL cookies tasty-PL ('the tasty cookie'/'the tasty cookies')

(40) Non-standard:

a bolacha gostosa / as bolacha gostosa
the-SG cookie tasty / the-PL cookie tasty
('the tasty cookie'/'the tasty cookies')

Our next task is to give an account of how this proposal takes care of the different interpretations of indefinites in generically quantified sentences. 


\section{Indefinites Participating in Generically Quantified Sentences: an analysis of the generic indefinite, the bare singular and the bare plural in Brazilian Portuguese}

This section will build an analysis of generic indefinites in Brazilian Portuguese based on the following claims made in the previous sections.

(i) The generic indefinite, the bare plural and the bare singular in generic sentences are all 'normal' heimian indefinites under the scope of a generic quantifier (Longobardi 1999 for the generic indefinite and for the bare plural in Romance languages, Müller 2000 for indefinites in BP).

(ii) The mass denotation of common nouns plus the number operators that turn mass nouns into count nouns account for the differences in the interpretation of indefinites in generic sentences in BP.

Recent work on genericity adopts an analysis of generically quantified sentences as sentences containing an unrealized relational generic operator (GEN) that takes a restrictor and a matrix (or nuclear scope) as its arguments as in (41) (Heim 1982, Wilkinson 1986, Gestner and Krifka 1993). Sentence (41) is an illustration of this account.

(41) a. Brasileiro dança bem.

b. GEN [x; ] ( $\mathrm{x}$ is-Brazilian; $\mathrm{x}$ dances-well)

c. 'Typically, if someone is Brazilian, he dances well'

If the indefinite singular, the bare singular and the bare plural are all 'normal' indefinites in Brazilian Portuguese, they get their generic meaning from the fact that they are participating on generically quantified sentences where their variable gets bound by the GEN(eric) operator. The challenge then is to account for the differences among the three forms.

Let's look at indefinites in the object position of habitual sentences. In this position the issue of the semantic number of the different indefinites shows up more clearly. First, let's look at the interpretation of the bare singular. The logical form of sentence (42a) says that Jorge usually reads an indefinite number of magazines or of parts of magazines after dinner. This is the reading that corresponds to native speakers' intuitions and that is in agreement with the fact that the bare singular is mass. 
(42) a. Depois do jantar, Jorge lê revista. After of-the dinner, Jorge reads magazine ('After dinner, Jorge reads magazines')

b. GEN [s; $\mathrm{x}]$ (Jorge in $\mathrm{s} \wedge \mathrm{s}$ is-after-dinner; $\mathrm{x}$ is-a-magazine $\wedge$ Jorge reads $\mathrm{x}$ in $\mathrm{s}$ ) $=$ GEN $[\mathrm{s} ;$ ] (Jorge in $\mathrm{s} \wedge$ after-dinner $\mathrm{s} ; \exists \mathrm{x}$ ( $\mathrm{x}$ is-a-magazine $\wedge$ Jorge reads $\mathrm{x}$ in $\mathrm{s})$ )

The meaning of the indefinite singular uma revista is built as in (43), where the indefinite article is vacuous as far as the logical form is concerned, but its presence implies that the singular operator has applied. The result is that the denotation of uma revista is made of atomic individuals. Sentence (44a) is then interpreted as the logical form in (44b) that means that Jorge usually reads at least one atomic magazine after dinner. This logical form is in accordance with our descriptive results as far as atomicity is concerned, but not as far as number is concerned. I then attribute the uniqueness constraint to pragmatics.

(43) uma revista $=\operatorname{uma}(\operatorname{SING}($ revista $))=\lambda \mathrm{x}$ [revista $(\mathrm{x}) \wedge \operatorname{At}(\mathrm{x})]$

(44) a. Depois do jantar, Jorge lê uma revista. After of-the dinner Jorge reads a magazine ('After dinner, Jorge reads a magazine')

b. GEN $[s ; x]$ (Jorge in $s \wedge s$ is-after-dinner; (uma (SING (magazine))) $(\mathrm{x}) \wedge$ Jorge reads $\mathrm{x}$ in $\mathrm{s}$ $=$ GEN $[\mathrm{s} ;]$ (Jorge in $\mathrm{s} \wedge \mathrm{s}$ is-after-dinner; $\exists \mathrm{x}(\lambda \mathrm{y}[$ magazine $(\mathrm{x}) \wedge$ At $(\mathrm{y})](\mathrm{x}) \wedge$ Jorge reads $\mathrm{x}$ in $\mathrm{s})$ ) $=\mathrm{GEN}[\mathrm{s} ;$ ] (Jorge in $\mathrm{s} \wedge \mathrm{s}$ is-after-dinner; $\exists \mathrm{x}$ ( $\mathrm{x}$ is-a-magazine $\wedge$ At $(\mathrm{x}) \wedge$ Jorge reads $\mathrm{x}$ in $\mathrm{s})$ )

As for the bare plural, I take the presence of plural morphology to indicate that the plural operator has applied as in (45). The denotation of the bare plural revistas is molecular, that is, it is made of sums of two or more magazines and that is the result we want. Sentence (46) with the bare plural is then interpreted as meaning that Jorge usually reads two or more magazines after dinner. And that is the expected reading.

(45) $\mathrm{PL}($ revista $)=\lambda \mathrm{P} \lambda \mathrm{x}[\mathrm{P}(\mathrm{x}) \wedge \operatorname{Mol}(\mathrm{x})]$ (revista) $=\lambda \mathrm{x}[\operatorname{revista}(\mathrm{x}) \wedge \operatorname{Mol}(\mathrm{x})]$ 
(46) a. Depois do jantar, Jorge lê revistas. After of-the dinner Jorge reads magazines'

('After dinner, Jorge reads magazines')

b. GEN $[s ; \mathrm{x}]$ (Jorge in $s \wedge \mathrm{s}$ is-after-dinner; $\mathrm{PL}($ revista) $(\mathrm{x}) \wedge$ Jorge reads $x$ in $s$ )

$=$ GEN $[s ;$; Jorge in $\mathrm{s} \wedge \mathrm{s}$ is-after-dinner; $\exists \mathrm{x}(\lambda \mathrm{y}$ [y is-a-magazine $\wedge \operatorname{Mol}(\mathrm{y})](\mathrm{x}) \wedge$ Jorge reads $\mathrm{x}$ in $\mathrm{s})$ )

$=$ GEN $[\mathrm{s} ;]$ (Jorge in $\mathrm{s} \wedge \mathrm{s}$ is-after-dinner; $\exists \mathrm{x}(\mathrm{x}$ is-a-magazine $\wedge$ $\operatorname{Mol}(\mathrm{x}) \wedge$ Jorge reads $\mathrm{x}$ in $\mathrm{s})$ )

We conclude that a mass denotation for common nouns in Brazilian Portuguese plus number operators that turn mass nouns into count nouns accounts for the interpretation of indefinites in generically quantified sentences.

\section{The Syntax and Semantics of Indefinites in Brazilian Portuguese: some consequences of the proposal}

The goal of this section is to analyze the correlation between syntactic structure and the interpretation of indefinites in subject position in BP.

Diesing 1988, 1992 claims that there is a correlation between the syntactic position of an indefinite and whether it is mapped into the restrictor or to the nuclear scope of a tripartite structure. Diesing's Mapping Hypothesis is presented in (47).

(47) Mapping Hypothesis (Diesing 1992):

a. Material from VP is mapped onto the nuclear scope.

b. Material from IP is mapped onto the restrictive clause.

According to Diesing 1992, subjects of individual-level predicates (I-level predicates) are generated outside the Verb Phase (VP). This implies that subjects of I-level predicates never get an existential interpretation. Also sentences with I-level predicates are not able to express a generalization over events because I-level predicates do not have an event argument. (cf. Kratzer 1995).

Subjects of stage-level predicates (S-level predicates), on the other hand, are generated inside the VP and then moved to the Specifier position 
of the Inflection Phrase (SpecIP). They allow for reconstruction at Logical Form. It follows then that sentences with S-level predicates should allow for both a generic and an existential reading for the indefinite in subject position. Since S-level predicates have an event argument, these sentences should also allow for a generalization over the event argument together with an existential reading for the indefinite (cf. Kratzer 1995).

We will see that indefinite subjects of I-level predicates are 'wellbehaved' in BP as far as Diesing's Hypothesis is concerned. The indefinite subjects in (48) only get a generic reading, the one represented in the logical form (49a) glossed as (49b). An existential reading as in (50a) glossed as (50b) - is not possible for indefinite subjects of I-level predicates as predicted by the Mapping Hypothesis.

(48) Um linguísta/Lingüísta/Lingüístas é/são inteligentes.

A linguist/Linguist/Linguists is/are intelligent

('Linguists are intelligent')

(49) a. GEN [ $\mathrm{x}]$ [x is-linguist $]$ [x is-intelligent]

b. 'Typically, if $\mathrm{x}$ is a linguist, $\mathrm{x}$ is intelligent'.

(50) a. \# $\exists \mathrm{x}(\mathrm{x}$ is-linguist $\wedge \mathrm{x}$ is-intelligent $)$

b. \# There are some intelligent linguists.

Let us now examine the behavior of indefinite subjects with S-level predicates. In habitual sentences as (51a), a generic interpretation for the bare singular is available (a generalization over the subject and over events) (52b). The same is true for the bare plural (52) and for the generic indefinite (53).

(51) a. (Ultimamente) médico anda trabalhando muito. ${ }^{11}$ Lately physician has-been working much ('Physicians have been working a lot lately')

b. GEN $\{x, s] ;[x$ is-physician $\wedge x$ in $s]$ [x is-working-a-lot- in $s]$

(52) Ultimamente médicos andam trabalhando muito. Lately physicians have-been working much ('Physicians have been working a lot lately')

11 The verb andar in $\mathrm{BP}$ is a light verb that is aproximately equivalent to the present perfect tense in English. Its original meaning is 'walk'. 
(53) Ultimamente um médico anda trabalhando muito. Lately a physician has-been working much ('A physician has been working a lot these days')

Unexpectedly, a generalization over events where the indefinites get an existential interpretation is not available for the bare singular (54a). Therefore, the logical form in (54b) is not available for a bare singular subject. Nevertheless, this interpretation is available for the bare plural and for the indefinite singular (55).

(54) a. Por aqui, médico anda trabalhando muito. Around here physician has-been working much (\#'There are typically physicians working a lot around here')

c. \#GEN [s is-here] $\exists x$ [ $\mathrm{x}$ is-a-physician $\wedge \mathrm{x}$ is-working-a-lot-in s]

(55) Por aqui, um médico/médicos anda trabalhando muito. Around here a physician/physicians have-been working much ('Around here there is/are typically a physician/physicians working a lot')

The same pattern occurs for the existential interpretation with episodic predicates. This interpretation is not available for the bare singular $(56 a, b)$. An existential interpretation is nevertheless possible for the bare plural and for the indefinite singular (57).

(56) a. *Médico está trabalhando muito (agora neste hospital). Physician is working much (now at this hospital) \#'There are some physicians working a lot (at this moment in this hospital)

d. $\# \exists x, s$ [ $\mathrm{x}$ is-physician $\wedge \mathrm{x}$ is- working-a-lot-in $\mathrm{s}]$

(57) Um médico está/Médicos estão trabalhando muito (agora neste hospital). A physician is /Physicians are working much (now at this hospital) ('A physician is/Physicians are working a lot (now at this hospital)'

We may conclude that the bare plural and the singular indefinite in $\mathrm{BP}$ are 'well-behaved' as far as the Mapping Hypothesis is concerned. On the other hand, bare singulars misbehave as far as the Mapping Hypothesis is concerned - they do not have the three interpretations predicted by the MP for S-level predicates. Why would that be? 
I will claim that the following theses explain the misbehavior of bare singulars in BP:

(i) The bare singular in BP is not a full DP, therefore it cannot be an argument. (cf. Longobardi 1994).

(ii) The bare singular in apparent subject position in BP is base generated outside IP (possibly a case of Clitic Left Dislocation). It is a topic - it is not a real argument of the VP. (cf. Casielles 1996 for Spanish, Barbosa et al. 2001 for Portuguese).

(iii) SpecIP is filled by a pro. Reconstruction may not occur.

Some data seem to support the hypothesis. First, bare singulars may not stay inside the VP as shown by their ungrammaticality in gerundive clauses (58a), which are grammatical both with the indefinite singular or the bare plural (58b).

(58) a. *Médico telefonando, eu peço pra atender você.

Physician calling I ask to see you

b. Um médico/Médicos telefonando, eu peço pra atender você.

A doctor/ doctors calling I ask to see you

('If a doctor/doctors call(s), I'll ask her to see you')

Partee 1991 claims that the topic-focus articulation of a sentence contributes to the formation of tripartite structures as expressed in (59). This explains why the bare singular in apparent subject position can only get a generic interpretation. Since it is generated outside IP and it is a topic, it is mapped to the restrictor and can only get a generic interpretation.

(59) a. Focus Material projects onto the nuclear scope.

b. Non-focused material projects onto the restrictive clause.

Although bare singulars are not grammatical as existential subjects of episodic sentences, they are fine in typical Clitic Left Dislocation (CLD) constructions (60), and may appear intermingled with clearly dislocated DPs $(61 \mathrm{a}, \mathrm{b})$ with episodic predicates.

(60) Médico sempre parece que pro está sempre telefonando. Physician always seems that pro is always calling ('Physicians always seem to be calling') 
(61) a. Emprego pra mim não está dando dinheiro. job to me not is giving money ('I'm not making money on jobs')

b. Pra mim emprego não está dando dinheiro. to me job not is giving money ('I'm not making money on jobs')

Also, if one takes that it is the SpecIP position that triggers agreement, it is significant that there is lack of gender and number agreement in predicative constructions with the bare singular (62a). Actually, the sentence becomes ungrammatical if the subject agrees in gender with the predicate (62b). On the other hand, both forms are perfectly grammatical with the indefinite singular (63) and the bare plural (64).

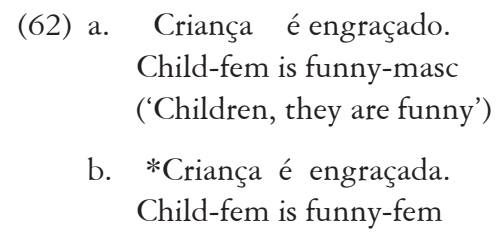

(63) Uma criança é engraçada/ engraçado. A child-fem is funny-fem/funny-masc ('A (certain) child is funny'/'A child (in general) is funny')

(64) Crianças são engraçadas /engraçado. Children-fem are funny-fem-pl/funny-masc ('Children are funny')

We can now make an interesting prediction. Since bare singulars are not full DPs, they are not real arguments of the verb. In object position they are possibly detransitivizing modifiers (cf. De Hoop 1996) or a case of predicate restriction (cf. Chung and Ladusaw 2001). This would explain why they are not affected by Quantifier Raising and do not get a widescope reading (cf. Schmitt \& Munn 2000).

Sentence (65) with the bare singular has only a narrow scope reading. The corresponding sentences with the indefinite singular (67) and with the bare plural (66) have both a narrow and a wide scope reading. 
(65) a. Jorge está procurando artigo de linguística para apresentar. Jorge is looking-for article of linguistics to present ('Jorge is looking for Linguistics articles to present')

(66) Jorge está procurando artigos de linguística para apresentar. Jorge is looking-for articles of linguistics to present ('Jorge is looking for Linguistics articles to present')

(67) Jorge está procurando um artigo de linguística para apresentar. Jorge is looking-for an article of linguistics to present ('Jorge is looking for a Linguistics article to present')

\section{Summary}

- The generic indefinite, the bare plural and the bare singular are predicates in BP. In generic sentences they are 'normal' indefinites under the scope of a generic quantifier.

- Common nouns have a mass-like denotation in BP.

- BP has a SG(singular) and a PL(ural) operator that turn a mass common noun into a count noun.

- Bare singulars are not full DPs. They are generated outside IP they are topics and always get a generic reading.

- The behavior of indefinites in BP seems to support the hypothesis that, when in generic sentences, they are not kind-referring expressions, but just 'normal' indefinites that get their variables bound by a generic operator.

- The behavior of indefinites in BP also seems to support Diesing's Mapping Hypothesis.

Recebido em agosto de 2001.

\section{REFERENCES}

Barbosa, P., A. Müller and F. Oliveira 2001. Nomes simples em posição de sujeito: questões sintaticas e semânticas. Paper presented at Colóquio Português Europeu e Português Brasileiro. Universidade do Federal do Ceará, Fortaleza, Brazil, 14-16 March.

Carlson, G. 1977a. A Unified Analysis of the English Bare Plural. Linguistics and Philosophy 1: 413-456. 
1977b. Reference to Kinds in English. Ph.D. dissertation, University of Massachusetts, Amherst. Published 1980 by Garland Press, New York. Carlson, G. \& F. J. Pelletier 1995. (eds.) The Generic Book. Chicago \& London: The University of Chicago Press.

Casielles, E. 1994. On the Misbehavior of Bare Nouns in Spanish. In: C. Brodi, C. Quicoli, M. Salterelli and M.L. Zubizarreta (eds.) Aspects of Romance Linguistics: selected papers from the Linguistic Symposium on Romance Languages XXIV. March 10-13.

Cheng, L.L-S. and R. Sybesma 1999. Bare and Not-so-Bare Nouns and the Structure of NP. Linguistic Inquiry 30 (4): 509-542.

Chierchia, G. 1998. Reference to Kinds across Languages. Natural Language Semantics 6: 339-405.

Chung, S. \& W. A. Ladusaw 2001. Restriction and Saturation in Chamorro Incorporation. Paper presented at The Semantics of Underrepresented Languages of the Americas (SULA). UMass, Northampton, MA, 20-22 April.

Diesing, M. 1988. Bare Plural Subjects and the Stage/Individual Contrast. In: M. KRIFKA (ed.) Genericity in Natural Language. SNS-Bericht 8842, Univerität Tübingen: 107-154.

1992. Indefinites. Cambridge, Mass: MIT Press.

Gestner, C. \& M. Krifka 1993. Genericity. In: J. Jacobs, A. von Stechow, W. Sternefeld, \& T. Vennemann (eds.) Handbuch der Syntax. Berlim: de Gruyter: 966-978.

Heim 1982. The Semantics of Definite and Indefinite Noun Phrases. UMass, Ph. D. dissertation.

Higginbotham, J. 1995. Mass and Count Quantifiers. In: E. Bach, E. Jelinek, A. Kratzer and B. Partee (eds.) Quantification in Natural Languages. The Netherlands: Kluwer: 383-419.

De Hoop, H. 1996. Case Configuration and Noun Phrase Interpretation. N. York \& London: Garland.

Krifka, M. , F. J. Pelletier, G. Carlson, A. Ter Meulen, G. Chierchia \& G. LinK 1995. Genericity: an Introduction. In: G. Carlson \& F. J. Pelletier (eds.): 1-124.

Link, G. 1983. The Logical Analysis of Plurals and Mass Terms: a Lattice Theoretical Approach. In: R. Bäuerle, C. Schwarze, and A. von SteCHOw (eds.) Meanining, Use and Interpretation of Language: 303323. Berlin: de Gruyter. 
Longobardi 1994. Reference and Proper Names: a Theory of N-Movement in Syntax and Logical Form. Linguistic Inquiry, 25: 609-665. 1999. How Comparative is Semantics. Univ. de Trieste. Manuscript. MülleR, A. 2000. The Expression of Genericity in Brazilian Portuguese. University of Massachusetts Occasional Papers 23: issues in semantics and its interface. K. KuUsmoto \& E. Villalta (eds.).

Munn, A. \& C. Sснмiтt 2000. Bare Nouns and the Morphosyntax of Number. Michigan State University. Manuscript.

Negrão, E. V. 2001. Distributividade em PB e a Exigência de Quantificação sobre Eventos. Working Papers dos Seminários em Teoria Gramatical 5. Universidade de São Paulo.

Negrão \& Muller 1996. As Mudanças no Português Brasileiro: substituição ou especialização? D.E.L.T.A. 12 (1): 125-172.

Partee, B. 1991. Topic, Focus and Quantification. SALT 1:159-187.

Wilkinson, K. 1991. Studies in the Semantics of Generic Noun Phrases. Ph.D. dissertation, University of Massachusetts-Amherst. 